\title{
Switching intentions in Telecom industry: a case of University students in Bahawalpur
}

\author{
Muhammad Rizwan \\ Lecturer, Department of Management Sciences, \\ The Islamia University of Bahawalpur, Pakistan. \\ Email: rizwan.arshad@iub.edu.pk \\ Muhammad Aurangzeb khan \\ MS Scholar, Department of Management Sciences \\ The Islamia University of Bahwalpur, Pakistn
}

Rabia khan

MS Scholar, Department of Management Sciences

The Islamia University of Bahwalpur, Pakistn

Saima shafiq

MS Scholar, Department of Management Sciences

The Islamia University of Bahwalpur, Pakistn

Accepted: September 13, 2013 DOI: 10.5296/jpag.v3i3.6226

\begin{abstract}
Consumers are the valuable assets of the organization as they are the ultimate destination of any product or services since they are the ultimate users of the any product or services thus the success of any organization depends upon the satisfaction of the customers, if not they will switch to other brands. The present paper attempt to study the consumer switching intentions in the telecommunication industry. The research aimed to find the reasons behind the customer switching behavior in cellular services sector of Pakistan. To conduct the research, we surveyed 170 respondents across the different departments in the ISLAMIA UNIVERSITY BAHAWALPUR. The survey was based on the self administered questionnaire. Respondents were selected on the random basis. After examining the collected
\end{abstract}


results, we inferred that the customer switching intentions mainly dependent on the price, core service failure and then the customer satisfaction. This research also confirms the negative effect of trust on switching .intentions .Trust can increase the loyalty of customer which decreases the intentions of consumers to switch. Using regression it is concluded that proposed variables have a significant relationship with the switching. Companies should focus on these factors to retain their customers and make them loyal enough that they could have a long retention period with the company.

Keywords: customer switching behavior in cellular industry, customer loyalty, Brand commitment

\section{Introduction}

Shoppers usually are precious assets for virtually every corporation. Buyer is definitely a personal or selection of those who select, obtain, use, or get rid of products, products and services, concepts, or encounters to fulfill needs and desires. To put it differently, Consumers are the final location involving any kind of offerings. The analysis of those men and women, teams, or businesses is that which you call up Buyer habits. This procedures with which these businesses select, safe, and get rid of products, products and services, encounters, or tips to gratify requirements plus the effects the procedures get within the client and society. The item mixes factors via mindset, sociology, societal anthropology and economics.

The achievement of any organization depends upon the satisfaction of the shoppers if not they will move to other brands. When any company losses the customer they are not only losing the future earnings but also experiencing the cost of finding the new customers. Over time faithful buyers become less price sensitive therefore losing loyal customers means surrendering high margins.

The item endeavors to recognize your choice making process, each separately and throughout teams. The item studies attributes involving person buyers including demographics and behavior parameters in an attempt to comprehend individuals would like. Furthermore, it tries to analyze impact on within the client via teams including household, pals, guide teams, and society generally. Purchaser habits research is dependent on client obtaining habits, while using client actively playing the about three distinctive jobs involving individual, payer and shopper.

Pakistan telecommunications sector is becoming on the list of most effective growing areas in the country. This wave inside telecommunications earth started in 2004 as soon as Pakistan Telecoms Authority (PTA) presented two varieties of permit regarding ISPs - regional as well as nationwide, and in addition exempted these individuals from Core Excise Work. Pakistan telecommunications marketplace website hosts a lot of the biggest and a lot effective international organizations on this planet. Cellphone marketplace of the telecommunications industry has observed a constant alter from monopolistic atmosphere to your highly reasonably competitive just one. The existing cellphone organizations supplying network service usually are Mobilink, Telenor, Ufone, Warid, as well as Zong.

Completely, Pakistan's Cellphone industry experienced tough budgetary year 2009-2010. 


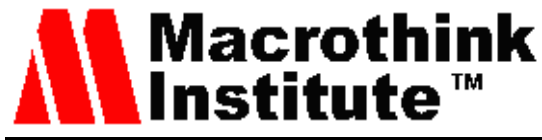

Journal of Public Administration and Governance

ISSN 2161-7104

2013, Vol. 3, No. 3

Hiked rates, reduced buying electrical power, electrical power dilemma, currency exchange accounting allowance as well as selling price conflict continued to be significant strikers to the cellphone organizations inside year 2009-2010. Industry's increase will be slowing down over the time frame, so brand new subscribers' addition will be cutting down as well as foreseeable future rivalry will likely be concentrated far more toward introduction involving revolutionary products/services to boost profits channels. Subscribers' retention \& acquisition involving buyers is already at the top involving to-do listings, along-with, support will probably enjoy critical purpose inside forthcoming days to weeks. One more subject of the fact that usually folks prefer to train on a solitary network as well as they do not like to frequently adjust their own services, although vast majority has used a couple of cellphone service as well as changed completely to another network due to on the list of components studied within this study. This particular study has become performed inside exact same link to find out the significance as well as significance involving different facets which influence a person to switch one's mobile phone service. Elements that produce people to move their own mobile phone are viewed as right after going over involving literature as well as prior studies inside exact same spot. Significance about these components has become looked into as well as significant components are already identified inside consequence section.

It is important to obtain standard details about the particular switching method to comprehend exactly why consumers move derived from one of model completely to another. Discerning the particular move structure of the consumer could be most successful regarding generating firm relationships with consumers (current as well as prospective) inside foreseeable future. Any kind of steps of the firm or perhaps service agency that originally makes the buyer or perhaps consumer take into consideration switching is referred to as the particular result in.

Switching intentions is not the latest study issue as well as preceding study offers examined numerous components leading to customer respect, for example perceived quality, customer confidence, and achievement. Keaveney (1995) ended up being the first for you to introduce the type of customer transitioning actions, containing nine key relaxed components which are crucial for you to transitioning actions, particularly, pricing, hassle, central service failures, service experience failures, as well as worker tendencies for you to service failures, aggressive concerns, honest difficulties as well as involuntary components. Moving over intention pertains to "Replacing as well as swapping the current vendor with another" (Bansal, 1997).

Moving over is really a intricate happening troubled by various components. That exploration paper aims to supply an extensive literature evaluate just for this happening as well as components of which Impact that.

Just as one introduction for the changing occurrence, you will find there's segment opinions relationship advertising and the most crucial aspects associated with the item, for example; customer happiness, faithfulness, believe in, WOM, perceived quality and price.

Intention pertains to it truly is the agent's specific goal in executing the steps as well as number of actions, the finish as well as objective that's targeted at. Final results which have been definitely not predicted and not foreseen are generally often known as unintentional 
penalties.

Services moving over pertain to your "act involving exchanging and also trading the actual service provider together with another which can be found towards the client already in the market (Bansal, 1997)". Usually customer satisfaction is available to get the most frequent issue impinging when moving over purposes (Fernandes and also Santos, 2007). Because deducted by Wen-Hua et 's., (2010) in the event that customers are generally enthusiastic about call up excellent, cellular gadget and also customer accentuate subsequently it negatively affect moving over purposes. Moving over purposes are generally highly suffering from understood price, understood excellent, primary assistance failure, customer satisfaction, recommendations, customer commitment and also believe in. Moving over purposes are generally high/increased while primary solutions are generally failure, perceived price is actually excessive, customer isn't gratify. Every one of these parameters get adverse relation together with moving over purposes. Moving over purposes are generally diminished while believe in, customer commitment, WOM are generally excessive. Every one of these parameters get adverse relation together with moving over purposes. The principle purpose of this article is to discover your parameters that effect the client moving over purposes. In this posting all of us acknowledged the consequence involving price, excellent, primary assistance failure, and full satisfaction on the moving over habits with the customers.

\section{Literature review}

The next portion presents the literary works examine with the goal changing practice, which includes a split in the variables influence it because primary or maybe moderating variables. The subsequent portion presents the literary works examine with regard to variables used in this kind of analyze, in which influence purchaser changing intentions. The next portion presents the literary works examine with regard to the most crucial scientific studies related to the particular changing sensation, as well as looks at the particular relative between all of them and also the provide analyze.

It has been seen from the existing literature that understanding behavior of consumer's i.e their needs and preferences has been studying over a time. Also, switching behavior of these buyers plays a vital role in the long term sustainability of the organizations. Thus the present study tries to understand the behavior of the mobile users and the various reasons for their switching to other services.

\section{INTRODUCTION OF PAKISTAN'S CELLULAR SERVICES SECTOR}

Throughout the the past few years, Pakistan has developed itself as being a cellular dependent nation supplying portable companies to help virtually all its cities. Till 2004, there have been some cellular agencies (Mobilink, Ufone, Insta, and also Paktel). Presently there can be fierce opposition concerning these service and also their particular qualities as soon as the entry of these corporations (Telenor and also Warid) within the telecommunication industry a provides fully malformed. Even though how many cellular service people has been improved quickly nevertheless the main thing can be of which "the cellular service people usually are switching derived from one of company on the various other more often than ever. 
For this reason the many carrier's networks are generally going through the difficulties associated with not merely getting brand-new consumer but in addition retaining the actual dealing with one particular. This factor is making the lenders to pay a lot more around the marketing and advertising as well as campaign prices such as brand-new plans as well as decline in the support fees. That's means the charge is now an excessive amount of higher to keep capable in this situation nevertheless the majority of the company are not able to prevent the buyers by moving over using their services

Industry in general is moving towards segmentation where specific user groups are coming up.

Total number of mobile subscribers reached more than 100 million in 2010 who were 93 million in 2009.

A record 9.34 millionsubscribers were added to total subscriber base of Pakistan in August 2010, which is the highest ever addition made in one month.

Share of Warid Telecom has increased from 4\% to $12 \%$ whereby Mobilink have lost their share in the market from $50 \%$ to $42 \%$ and $4 \%$ to $1 \%$ respectively.

There is an addition of about 1 million subscribers every month from the last year.

Average Revenue per user (ARPU) of Pakistan Mobile Industry for the year 2010 (Calendar Year) has dropped from US\$2.83 per month in 2009 to US\$2.66 in 2010.

More than 10,000 cell sites have been erected by mobile operators till 2010 .

\subsection{Mobilink}

Pakistan Cell phone Marketing and sales communications Minimal, better generally known as Mobilink GSM is famous, is usually a service provider involving telecommunication products and services within Pakistan. The organization would be the most significant portable agent within Pakistan, thirty-one. 5 thousand consumers along with a current market share involving $31 \%$ within Oct 2010.

The key head office is found at Kohistan highway, F-8 Markaz Islamabad. Mobilink as soon as the merging from the software programs operating beneath the company, indigo, distributed as well as paid for to talk about "jazz".

Mobilink started out within 1994 for the reason that very first GSM service within Pakistan, Motorola Inc., in the future distributed to Orascom, Egypt on an global basis.

\subsection{Ufone}

PTML, 100\% regarding PTCL may be developed to provide cellphone GSM 900 cell phone solutions; firm started it is pursuits beneath brand name Ufone Islamabad Present cards twenty nine, 2001. Ufone invests lots with the extension regarding insurance policy coverage and brand-new cities and streets of these network insurance policy coverage. Ufone presently 
includes greater than 100 major metropolitan areas and freeways through Pakistan, the very best support services and value for money.

\subsection{Warid Telecom}

Warid Telecommunications Global Abu Dhabi Organization provides mobile companies inside the Congo, Pakistan as well as Uganda. Warid is actually that the Ivory Coast as well as Georgia shortly can be expected. Within 2004, Warid Telecommunications Global LLC, provides acquired permits to be able to carryout a new national circle mobile phone (WLL) as well as long-distance intercontinental (LDI) regarding bucks 291 mil, because primary organization associated with Warid Telecommunications Global LLC.

Warid Poland provides launched the particular services inside Might 2005. The actual transactions inside 50 nights following premiere associated with Warid Pakistan, provides drawn greater than 1 mil customers.

In July 40, 2007 provides released in which Singapore Telecommunications Limited (SingTel) as well as Warid Telecommunications include the remaining contract following buy associated with 40 dollars regarding Warid Telecommunications, SingTel inside about bucks 758 mil - an present which is well worth the significance associated with 2, 900 mil money. Warid Pakistan intends to offer both equally postpaid as well as pre paid services. Post-paid plan is actually brand name as well as sold beneath name Zahi postpaid near you, this means leader or even movie stars. Message pre-paid as well as publicized while Zem pre paid.

User-ZahiZem pre paid as well as postpaid companies make use of a number of value-added companies (VAS), such as TEXT MESSAGE, MMS, GPRS, 64K SIM, Two SIM products, the corporation promotion with the TEXT MESSAGE packages and lots of various other attributes.

\subsection{Telenor}

Telenor Party, the telecom business throughout Norway, near Oslo, located in Fornebu. Today, Telenor Party is an global user connected with cell connection, based mainly throughout Scandinavia, Far eastern The european countries in addition to Japan,

doing work mainly for your label of Telenor. Today, it is the 6th portable user on this planet with an increase of than 203 thousand clients. Additionally, it carries a prosperous in addition to broadband television set submission throughout a number of Nordic international locations in addition to decade connected with research in addition to market for a appliance to appliance technologies.

Telenor Pakistan is usually wholly-owned operations upon Goal 15 commenced throughout 2005 which is one of 6-8 portable telephone systems license throughout Pakistan. This 'also your speediest community connected with cellular growth throughout Pakistan : this could be assigned to aggressive marketing and advertising campaign. Telenor at the moment retains the 2nd GSM in addition to GPRS in addition to ADVANTAGE, in addition to England, which competes with Ufone. Using the current launch of the nation's ADVANTAGE community enabled. This can be a next greatest shop throughout Pakistan inside of a couple 
of years with their actions in addition to place into functioning inside upper areas of Pakistan in addition to Azad Kashmir (AK). Telenor provides achieved the harmony inside initial fraction connected with 2007. Telenor is an productive humanitarian in addition to combats for the health of your patients in the huge amounts throughout Balochistan. Past Leader connected with Telenor Pakistan is usually Christian Albech.

\subsection{Zong}

Zong is the first international brand of China Mobile in Pakistan in 2008, at the end of year. The company is often cited as China Mobile (Pakistan). Zong CSR activities to support scholarships for students at the University of Technology (Peshawar) and entertainment to the world of dreams, the option for the perception of the emotional family ties.

\subsection{Paktel}

Paktel Mobile is a company that has started and finished in mobile telephony in Pakistan. Since then, our customers and Paktel long way in the Pakistanis came the way of communication. From simple one-to-one voice communication, customers can now Short Messaging Service (SMS), MMS, polyphonic ring tones, conference calling, call transfer and many other interesting services.

\subsection{Insta phone}

Instaphone introduced to Pakistan mobile in 1991.Today; name is synonymous with high quality for the money. Its product portfolio includes a variety of plans tailored to different market segments. Instaphone has a range of revolutionary glory on the network continues to grow to 185 cities and a pioneer in customer-friendly initiatives, such as prepaid plans, the caller pays, low-end prepaid cards, 12 months free entry, inbound roaming services, SMS and international SMS.

Parameters which influence the particular changing intentions usually are recognized cost, central service failing, Client satisfaction, Observed good quality, purchaser respect, believes in as well as recommendations (WOM).

\section{Switching intentions}

Customer switching management is a phrase that applies for expressing the loss of customer due to various reasons. To be more accurate, customer switching management means detecting customers that are on the threshold of leaving use of organization services and using the services of other rivals ( hadden et al, 2005)

Many scientific studies are actually completed to find out these components of which impact your decision to help maintain while using the very same service or product in order to undertake yet another service or product. Several scientific studies uncovered of which consumer changing behaviour tremendously is dependent upon the amount of full satisfaction or perhaps dissatisfaction.

Client changing may be the built in tendency of the consumer relinquishment coming from ongoing this deal relationship having a organization in the time period ( Chandar et 's, 2006). 
Based on that definition, some sort of churner consumer will be someone which cut most his or her activities with organization (Van den Poel 2005).

\section{Perceived quality}

“Grönroos (1982) identified support top quality as being a customer's understanding regarding Difference between predicted support and also the understood service". When the rope outlined the thought of understood support top quality as the outcome of an assessment method, the spot that the client analyzes his or her anticipations while using support this individual interprets or maybe possesses been given (ibid). Case study regarding support top quality has been pioneered by simply PZB, exactly who designed the particular breaks platform with 1985 and it is related SERVQUAL

Instrument with 1988 (Parasuraman et al., 1985, 1988, 1991). Several variety of scholars did consent to the fact that support top quality is usually represented by the dual-dimension method (Grönroos, 1983; Lehtinen \& Lehtinen, 1982). The primary dimensions relates to just what the particular support actually gives and is known as by simply PZB (1985) since "outcome quality" and by simply Grönroos (1984) since "technical quality". The 2nd dimensions relates to the fact that support can be delivered. PZB (1985) identified the idea since "process quality" though Grönroos (1984) classified the idea since "functional quality". Parasuraman and Zeithaml (2006) outlined support top quality since "the degree and direction regarding difference involving customers' support ideas and expectations”.

Khatibi et al. (2002) tracked a direct and constructive result regarding understood support top quality with customer happiness. Empirical scientific tests in a range of professional options supply a compelling evidence for just a direct relationship involving support top quality and client respect (Zeithaml et al., 1996; Cronin et al., 2000).

\section{Satisfaction}

Client satisfaction is usually an entire frame of mind formed dependant on the knowledge after shoppers obtain a product or utilize a service(Fornell, 1992)". It is just a manifestation to be quite happy with such aproduct or even a service.

"Satisfaction may be the evaluation of the experience of reaching something supplier way up to the current occasion, and is also utilized by shoppers for you to predict long term practical knowledge (Crosby et al., 1990)". "Satisfaction is usually a vast feeling, and that is affected by service good quality, product good quality, price tag, in addition to contextual in addition to particular factors (Zeithaml \& Bitner, 2000)". Achievement is amongst the antecedents associated with consumer devotion. Throughout earlier reports, fulfillment absolutely has effects on consumer devotion (de Ruyter \& Wetzels, 2000; Deng, Lu, Wei, \& Zhang, the year just gone; Prick \& Basu, 1994). Even though the motive that will shoppers remain faithful may well not regularly be fulfillment (Gerpott, Rams, \& Schindler, 2001), it is protected to convey that will pleased shoppers are more faithful. Empirical data shows that will customer happiness is drastically linked to behavior devotion within fiscal service industries. 


\section{$\Lambda$ Macrothink}

\section{Core services failure}

2013, Vol. 3, No. 3

Consumers likewise switch on account of primary support malfunction. It is the largest cause on account of that customer changes derived from one of organization to a different. It includes 3 subcategories: (1) mistakes, (2) payment glitches, as well as (3) support catastrophes. Program Encounter is the term for an individual cans interaction concerning buyers as well as staff members involving providers. it is the second largest group on account of that customer changes derived from one of organization to a different. It includes the actual several aspects of support employee's behaviors as well as his or her mind-set. It includes (1) uncaring, (2) rude, (3) unresponsive as well as (4) unknowledgeable staff members. That group pertains to the grade of the actual friendships concerning buyers along with the staff members of the support companies, and that is involving fast importance to cellular phone providers and various support companies. Program experience malfunction involves undesirable thinking through

Program agency staff members, the actual unresponsiveness to customers' problems,

The of poor quality ways in dealing with buyers, along with the malfunction involving support providers' call centers to offer assist.

Far east buyers tend to be much less requiring intended for support high quality and therefore are so unlikely compared to his or her American counterparts to switch providers on account of weak customer satisfaction experience.

\section{Price}

Philip Kotler identified "Price is actually how much cash billed for any services or products."

Higher price tag would be the next most common basis for transitioning objectives. The actual initial analyze signifies that the main epidermis advantages of consumer transitioning habits is actually large support price tag. The actual element research helps this specific discovering that large price tag would be the only one item element amid the many types of support transitioning habits. Selling price ended up being discovered for being a great important element intended for consumer transitioning objectives within insurance agencies. (Anton et ing. 2007. ) khan et ing. (2010) also confirmed their bond concerning price tag and transitioning objectives.

\section{WOM}

Consistent with the role regarding full satisfaction within cutting down transitioning tendency, pleased consumers can also be recognized to engage in WOM behaviors (Brown et al., 2005; Swan and Oliver, 1989; Westbrook, 1987). On the other hand, remarkably minor study possesses focused on this specific link. Positive WOM behaviors can be a crucial marketing instrument, if properly gathered through the agency (Silverman, 1997).

\section{Customer loyalty}

Faithfulness have been looked as "a deeply used motivation to be able to rebuy or even 
repatronize any recommended product/service consistently from the future" (Oliver, 1999, p. 34). Buyer respect possesses two symbolism:

Long-term and the short-term respect (Jones \& Sasser, 1995). Consumers using long-term respect do not quickly swap to be able to some other companies, though clients using short-term respect defect more readily whenever made available any observed much better alternative.

It can be beneficial for companies to establish any romantic relationship using clients which clients would like to hold on to. Inside Taiwan, the actual portable services market place is extremely condensed and also profit margins are usually at standstill. In this predicament, it is far better to be able to hold on to existing clients than sponsor completely new types (Ahmad \& Buttle, 2002; Fornell, 1992). The importance associated with buyer respect is it closely pertains to the actual company's ongoing success, and strong upcoming growth. For this reason, for just a organization to keep a reliable revenue level if the request level possesses reached the actual vividness point, the market industry is older, and also competition is crazy, any shielding method that aims to be able to hold on to existing clients is more crucial than a ambitious 1 , that stretches the length of the market place through inducting customers

(Fornell, 1992; Ahmad \& Buttle, 2002).

\section{Trust}

Confidence has become looked as "one get together assuming which the other get together will fulfill their needs". Regarding providers, " rely on would be the belief held with a client which the service agency can provide the particular service which fulfills client wants (Anderson\&Weitz, 1989)".

An even more normal description regarding rely on is that your get together has confidence within the honesty and consistency regarding his / her spouse (Morgan \& Search for, 1994).

You can find a pair of levels of rely on, as outlined by Rauyruen and Miller(2007). On the very first level, the buyer trusts a definite revenue representative while in the next level, the buyer trusts the particular establishment. Within portable info service, client rely on is out there a lot more in the next level. Consumers rely on the particular service agency all together simply because over the strategy of becoming a member of providers, transforming providers, and support, it is also possible which revenue staff are wide and varied. More, numerous providers can be purchased by using the internet and there's often you should not interact with a genuine person at all. Hence client rely upon some sort of portable info service agency is less in connection with a definite revenue representative.

Confidence can be an critical mediating aspect between client conduct previous to and immediately after buying a product. The item may result in long-term faithfulness and fortify the partnership relating to the pair of celebrations (Singh \& Sirdeshmukh, 2000). Like with faithfulness, rely on is especial psychological declare that could merely happen in a few associations. If a client trusts a business, the individual has got the confidence operating quality and product quality in the business. 


\section{Macrothink

Consumers whom rely on a business usually are probably being devoted for the organization (Garbarino \& Manley, 1999. Within previous study, rely on has become conceptualized as antecedent regarding satisfaction (e. g., Palvia, 2009). Within this study we're keen on the particular primary consequences regarding satisfaction and rely on, as different parts of partnership quality, with client faithfulness. Hence, this theory is proposed.

\section{MODEL}

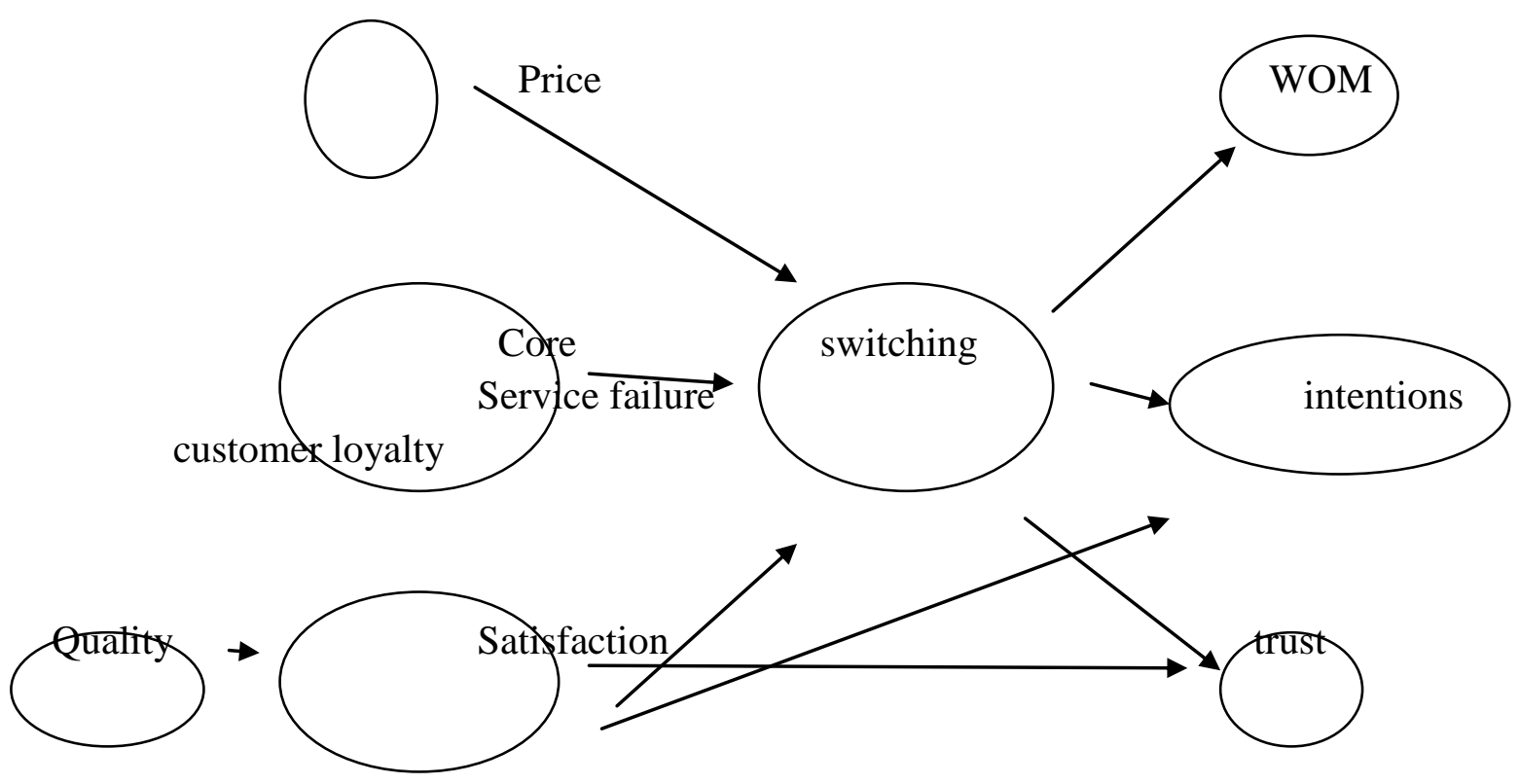

\section{Hypotheses:}

H1: There is a positive relationship between perceived Quality and customer satisfaction.

H2: There is a Negative relationship between customers Satisfaction and switching intentions.

H3: There is a positive relationship between core service failure and switching intentions.

H4: There is a positive relationship between perceived price and switching intentions.

H5: There is a Negative relationship between switching intentions and words of mouth.

H6: There is a Negative relationship between switching intentions and customer loyalty.

H7: There is a Negative relationship between switching intentions and the trust. 


\section{Research methodology}

The current research is casual in its nature. Casual research design is the study that explores the effect that one thing has on another thing. The research is done in a thorough way that shows the effect that each variable has on the each thing

To test the proposed research model as shown in Fig. 1, a questionnaire research methodology was used. In this section, details of research design, questionnaire distribution and procedures are reported. In this research, describe relationship between perceived prices, core service failure, and perceived quality, Satisfaction, trust, WOM and loyalty.

\section{Sample/Data}

The major objective of this study to explore switching intentions of customers of cellular company in Pakistan and effect of other variables on switching intentions.

Measures for perceived quality consisted of five items based on Yoo et al (2000). A four item scale adapted from was used as the measure of switching intentions. Measures for WOM consisted of four items, which were adapted from.

Satisfaction was measured by a four item scale based on Ragunathan and Irwin (2001) .Trust was measured by a five-item scale adapted from Matzler it al, (2008). Chanduhuri and Holbrook,(2001). Satisfaction scales were based on measures of perceived quality. The four -item scale for brand loyalty was adapted from (Chaudhuri and Holbrook, 2001; Oliver, 1997; Pritchard et al., 1999; Sirdeshmukh et al., 2002. A four item scale adapted from was used as the measure of perceived price. The items were constructed using a 5-point -Scale ranging from strongly agree to strongly disagree $(1=$ strongly agree; $5=$ strongly disagree $)$.

It has ensured that the sample members should have main qualification to participate in the self administered survey. The sample member should be using mobile.

\section{Instrument and Measure}

The survey instrument of the present study having two major purposes: First is to measure the relationship of different variables in switching intentions of customers of cellular company in Pakistan

Second, to collect information about the different characteristics of the respondents that can be used to understand the variations in different categories.

The survey instrument consists of two sections. Section 1 includes different personal and demographic variables. This section will obtain the respondent's information about gender, age, income, education, status, usage of network of mobile phone.

Section 2 includes the hidden variables that are important in the current study. These variables includes perceived quality, perceived price, WOM, brand trust, brand loyalty, customer satisfaction, core service failure. 


\section{Macrothink}

\section{Procedure}

A self administrated questionnaire was distributed to mobile phone users. A convenient sample was used. Paper surveys were distributed on the campus of Islamia University to students and their families. The population for the current research is mobile phone users.A total of 170 questionnaires were distributed and 151 valid questionnaires were returned. These respondents are selected based on the criteria above mentioned. Before giving the questionnaire, the purpose of study and questions were explained to the respondents so they can easily fill the questionnaire with relevant responses. After collecting the completed questionnaires, these questionnaires were coded and entered into SPSS sheet for further analysis.

\section{Reliability Analysis}

Overall Cronbach's alpha of switching intentions questionnaire items were 0.754 that is more than acceptable and recommended value 0.50 by Nunnally (1970) and 0.60 by Moss et al. (1998). This shows that all the 34 items were reliable and valid to measure switching intentions of consumer.

\section{Reliability of Measurements Instrument}

\begin{tabular}{|l|l|l|}
\hline Scales & Items & Cronbach's alpha \\
\hline Switching intentions & 4 & .825 \\
\hline Perceived quality & 5 & .788 \\
\hline Perceived price & 4 & .793 \\
\hline Brand Trust & 5 & .842 \\
\hline Core service failure & 4 & .548 \\
\hline Satisfaction & 4 & .771 \\
\hline Brand loyalty & 4 & .769 \\
\hline WOM & 4 & .696 \\
\hline
\end{tabular}

\section{Hypotheses Testing}

\section{Profile of the Respondents}

Personal and demographic information such as gender, age, income, education level, status of respondent are presented in the following table 


\begin{tabular}{|c|c|c|c|}
\hline & Category & Frequency & Percentage \\
\hline \multicolumn{4}{|l|}{ Variable } \\
\hline Gender & $\begin{array}{l}\text { Male } \\
\text { Female } \\
\text { Total }\end{array}$ & $\begin{array}{l}67 \\
84 \\
151\end{array}$ & $\begin{array}{l}44.4 \\
55.6 \\
100.0\end{array}$ \\
\hline Age & $\begin{array}{l}\text { 15-20years } \\
\text { 20-25years } \\
\text { 25-30years } \\
30-35 \text { years } \\
\text { 35-40years } \\
\text { above } 40 \text { years } \\
\text { Total }\end{array}$ & $\begin{array}{l}43 \\
88 \\
14 \\
2 \\
3 \\
1 \\
151\end{array}$ & $\begin{array}{l}28.5 \\
58.3 \\
9.3 \\
1.3 \\
2.0 \\
.7 \\
100.0\end{array}$ \\
\hline Income & $\begin{array}{l}\text { below } 15000 \\
15000-25000 \\
25000-35000 \\
35000-45000 \\
45000-55000 \\
\text { above } 55000 \\
\text { Total }\end{array}$ & $\begin{array}{l}96 \\
19 \\
13 \\
10 \\
7 \\
6 \\
151\end{array}$ & $\begin{array}{l}63.6 \\
12.6 \\
8.6 \\
6.6 \\
4.6 \\
4.0 \\
100.0\end{array}$ \\
\hline Education & $\begin{array}{l}\text { matriculation } \\
\text { inter } \\
\text { bachelor } \\
\text { Master } \\
\text { Ms/Mphil } \\
\text { PHD } \\
\text { Total }\end{array}$ & $\begin{array}{l}1 \\
4 \\
60 \\
49 \\
36 \\
1 \\
151\end{array}$ & $\begin{array}{l}.7 \\
2.6 \\
39.7 \\
32.5 \\
23.8 \\
.7 \\
100.0\end{array}$ \\
\hline
\end{tabular}




\begin{tabular}{|l|l|l|l|}
\hline Status & student & 117 & 77.5 \\
Employed & 31 & 20.5 \\
Businessmen & 1 & .7 \\
Unemployed & 1 & .7 \\
Housewife & 1 & .7 \\
Total & 151 & 100.0 \\
\hline \multirow{2}{*}{ Usage } & Mobilink & 41 & 27.2 \\
& Ufone & 57 & 37.7 \\
Zong & 17 & 11.3 \\
& Warid & 13 & 8.6 \\
& Telenor & 23 & 15.2 \\
& Total & 151 & 100.0 \\
\hline
\end{tabular}

\section{Hypothesis Testing}

\section{Perceived quality, customer satisfaction and switching intentions}

Regression Analysis of the switching intentions model shows that there is a significant positive relationship between perceived quality with $(\beta=0.647)$ and $(p<0.00)$. The results suggest that perceived quality contribute almost $50 \%$ to customer satisfaction. The results of study support $\mathrm{H} 1$.

\section{Customer's satisfaction and switching intentions}

While considering the significance between switching intentions and customer satisfaction, the results of the current study shows significant relationship between these two variables with

$(\beta=-.132)$ and $(p>0.025)$. These results of the study validate $H 2$.

\section{Core service failure and switching intentions}

The regression results of the study confirm the significant relationship between core service failure and switching Intention with $(\beta=0.215)$ and $(\mathrm{p}<0.009)$. According to these results, core service failure contributes more than $21 \%$ to switching Intention. These results of the study validate $\mathrm{H} 3$. 


\section{Macrothink \\ Journal of Public Administration and Governance \\ ISSN 2161-7104 \\ 2013, Vol. 3, No. 3}

\section{Perceived price and switching intentions}

According to the results of the study, the both variables of Price have an insignificant positive relationship with switching intentions. Specifically, the price has a significant positive relationship with $(\beta=0.008)$ and $(p<.928)$. That means the price contribute more than $8 \%$ to switching intentions. The regression results of Price with switching intentions is insignificant with $(\beta=0.008)$ and $(p<0.928)$. Results of the current study validate the H4.

\section{Switching intentions and Words of mouth}

While considering the significance between switching intentions and words of mouth, the results of the current study shows significant relationship between these two variables with $(\beta=0.188)$ and $(p>0.021)$. Words of mouth contributes more than $18 \%$ to switching Intention. These

Results of the study validate H5.

\section{Switching intentions and Customer loyalty}

Regression estimates results show that Customer loyalty found significantly related with switching intentions. There is a significant negative relationship between customer loyalty and switching intentions and customer loyalty with $(\beta=-0.198)$ and $(p<0.015)$. These Results of the study validate H6.

\section{Switching intentions and Brand Trust}

The regression results of the study confirm the significant negative relationship between brand trust and switching Intention with $(\beta=-.327)$ and $(p<0.000)$. These results of the study validate H7.Table 6 summarizes the regression results of the study and Figure 2 shows the graphical presentation of the structural model.

\section{Regression result}

\begin{tabular}{|c|c|c|c|c|c|c|}
\hline $\begin{array}{l}\text { Hypothe } \\
\text { sis }\end{array}$ & Model variable & $\begin{array}{l}\text { Estim } \\
\text { ate }\end{array}$ & S.E. & C.R & $\mathbf{P}$ & Result \\
\hline H1 & $\begin{array}{l}\longleftarrow \\
\text { satisfaction } \\
\text { Quality }\end{array}$ & .647 & .61005 & $\begin{array}{l}10.35 \\
5\end{array}$ & .000 & Supported \\
\hline H2 & $\begin{array}{l}\text { S.intentions } \\
\text { satisfaction }\end{array}$ & -.132 & $\begin{array}{l}1.0180 \\
8\end{array}$ & $\begin{array}{l}-1.46 \\
5\end{array}$ & .025 & Supported \\
\hline H3 & $\begin{array}{l}\text { S.intentions } \\
\text { C.S.F }\end{array}$ & .215 & $\begin{array}{l}1.0180 \\
8\end{array}$ & 2.666 & .009 & Supported \\
\hline H4 & $\begin{array}{l}\text { S.intentions } \\
\text { Price }\end{array}$ & .008 & $\begin{array}{l}1.0180 \\
8\end{array}$ & .091 & .928 & Not supported \\
\hline
\end{tabular}




\begin{tabular}{|l|l|l|l|l|l|l|}
\hline H5 & $\begin{array}{l}\text { S.intentions } \\
\text { WOM }\end{array}$ & .188 & .85306 & 2.337 & .021 & Supported \\
\hline H6 & $\begin{array}{l}\text { S.intentions } \\
\text { Br_loyalty }\end{array}$ & -.198 & .83065 & $\begin{array}{l}-2.46 \\
3\end{array}$ & .015 & Supported \\
\hline H7 & $\begin{array}{l}\text { S.intentions } \\
\text { Br_Trust }\end{array}$ & -.327 & $\begin{array}{l}1.0740 \\
4\end{array}$ & $\begin{array}{l}-4.22 \\
\text { _. }\end{array}$ & .000 & Supported \\
\hline
\end{tabular}

\section{Discussion}

The aim of this study is investigating the effective on consumer switching behavior in mobile phone service provider industry, on this purpose according to study of literature the variables are Per.Qua,C.Sati, C.S.F, B.Loy, Per_pri.

B_Tru and WOMo are identified. On basis of above research pricing is not a big reason due to which the customer leaves from one service provider to another. While analyzing the relationship it appears that Qua. has strong and significant relationship with C.Sati .It also confirms the negative effect of C.Sati. on switching intentions.

To conclude, two relational factors namely Qua. and Sati. significantly predict switching barriers and among these, Sati. is the strongest predictor. Study reveals the positive significant role played by the relational factors in predicting C.Loy. or discouraging customer switching. The result of third hypothesis shows the direct effect of C.S.F with switching intentions. The result of second hypothesis of the research confirms the negative effect of customer satisfaction on switching.In most researches significant relationship of satisfaction and switching behavior has been emphasized.As an example Ye et al (2006) have shown that customer satisfaction has negative effect on consumer switching intentions.

This research also confirms the negative effect of trust on S.int.Trust can increase the loyalty of customer which decreases the intentions of consumers to switch.

\section{Managerial implications}

This research offers implications for management of customer relationship. Our findings shows that service brand managers, particularly those in relational services should recognize the key role of customer satisfaction in managing current customers. The generation of customer satisfaction and brand loyalty are particularly important in developing WOM and reducing switching intentions.

To gain customer loyalty, service provider's management ought to satisfy its customers, which can be implemented only when customers needs are known, which can be achieved through a meaningful customer feedback on a continuous basis. It is well known that cost of retaining a customer is much less than cost of acquiring new customers. 


\section{Limitations and Future researches}

Besides these findings, the current study open several areas to be explored in the future research. The current study only focuses on intention of the customer, which do not always become actual behavior. Our research area was mainly for the students of Islamia University Bahawalpur. As our sample was consisted of 170 respondents out of which we got only 151 feedbacks from them. Our research was limited only to the telecommunication sector.

Future result can examine the value of switching rather than focusing on the negative aspects of switching. Moreover, the impact of commitment, switching cost. Switching barriers, performance and rivals on switching intentions can also be studied in future. Last, similar study can be replicated to provide valuable research findings for other related services like banks, airlines, hospitals, insurance etc.

\section{References}

Anto n, C., Camarero, C., and Carrero, M. "Analysing Firms' Failures as Determinants of Consumer Switching Intentions: The Effect of Moderating Factors," European Journal of Marketing (41:1/2) 2007, pp 135-15

Bansal, H.S(1997), "service switching model (SSM): a model of customer switching behavior in Service Industry”. Published by UMI, Queen's University Kingston , Ontario Canada

Brown et al (2005) spreading the word : investigating antecedents of consumer's positive words of mouth intentions and behaviors in a retailing context. Journal of the Academy of Marketing Sciences 33 (2), 123-138

Chandar m., Laha . A\&Krishna p, (2006), modeling churn behavior of bank customers using predictive data mining techniques. In national conference on soft computing techniques for engineering applications, March 24-26

Crosby LA, Evans KR, Cowles D. Relationship quality in services selling:an interpersonal influence perspective. J Mark 1990;54(3):68 -81.'

Chaudhuri and Holbrook, 2001; Oliver, 1997; Pritchard et al., 1999; Sirdeshmukh et al., 2002 de Ruyter, K., Wetzels, M. and Bloemer, J. (1998), "On the relationships between perceived service quality, service loyalty and switching costs”, International Journal of Service Industry

Management, Vol. 9 No. 5, pp. 436-53.

Dick, A.S. and Basu, K. (1994), "Customer loyalty: toward an integrated conceptual framework",Journal of the Academy of Marketing Science, Vol. 22 No. 2, pp. 99-113.

Fornell, Claes. (1992). A National Customer Satisfaction Barometer: The Swedish Experience. Journal of Marketing, 56 (January), 1-18. 


\section{$\triangle$ Macrothink}

Journal of Public Administration and Governance ISSN 2161-7104

Grönroos, Christian, 1982. Strategic Management and Marketing in the Service Sector. Research

Reports No. 8. Swedish School of Economics and Business Administration, Helsinki.

Grönroos, Christian, 1983; 1987; 1996. Marknadsföring i tjänsteföretag. Stockholm: Liber förlag.

Grönroos, Christian, 2000. Service Management and Marketing: Managing the Moments of Truth in Service Competition. London: Wiley

Lehtinen J.R., lehtinen U. 1982. Service quality: a study of quality dimensions, unpublished working paper, Service Management Institute Helsinki

Gerpott, T.J., Rams, W. and Schindler, A. (2001), "Subscriber retention, loyalty, and satisfaction in the German mobile cellular telecommunications market", Telecommunications Policy, Vol. 25 No. 4, 249-69.

Hadden j., tiwari A., Roy R Ruta D. (2005) 'computer assisted customer churn management : state-of-the-art and future trends' computers \& operation research, 34:10, pp. 2902-2917

Jones, T.O. and Sasser, W.E. (1995), "Why satisfied customer defect", Harvard Business Review,Vol. 73 No. 6, pp. 89-99.

Khatibi, A.A., Ismail, H. and Thyagarajan, V. (2002), "What drives customer loyalty: an analysis from the telecommunications industry", Journal of Targeting, Measurement and Analysis for Marketing, Vol. 11 No. 1, pp. 37-52.

Keaveney, S.M., 1995. Customer switching behavior in service industries: an exploratory study. Journal of Marketing 59 (2), 71-82.

Kottler P. (1994) Marketing Management, prentice-hall, Englewood Cliffs, NJ

Morgan, R., \& Hunt, S. (1994). The commitment-trust theory of relationship marketing. Journal of Marketing, 58, 20-38.

Matzler it al, (2008). Chanduhuri and Holbrook,(2001).

Oliver RL. Whence consumer loyalty? J Mark 1999;63(Special issue):33-44.

Parasuraman, A., Zeithaml, V. A., \& Berry, L. L. (1985). A conceptual model of service quality and its implications for future research. Journal of Marketing, 49, 41-50.

Parasuraman, A., Zeithaml, V. A., \& Berry, L. L. (1988). SERVQUAL: A multiple-item scale for measuring consumer perceptions of service quality. Journal of Retailing, 64(1), 12-40.

Parasuraman, A., Zeithaml, V. A., \& Berry, L. L. (1991). Refinement and reassessment of the SERVQUAL scale. Journal of Retailing, 67(4), 420-450.

Parasuraman, A., Zeithaml, V. A.,(2006). Understanding and improving service quality : a literature review and researcha agenda in B. Weitz and R.Wensley (Ed.) handbook of marketing, London : Sage Publications 
Ragunathan and Irwin(2001

Swan J.E and oliver R.L 1989. Post purchase communications by consumers .Journal of Retailing 65 (4), 516-533

van den Poel , lariviere., (2004). Customer attrition analysis for financial services using proportional hazard models. Eurpeon journal of operational research 157, 196-217

Westbrook, Robert A., 1987. Product/Consumption-Based Affective Responses and Post purchase Processes. Journal of Marketing Research, Vol. 24, pp. 258-270, August

Yoo et al (2000).

Zeithaml, V. A. \& Bitner, M. J. (1996), Services Marketing, McGraw-Hill, New York, NY.

Cronin, J. J., \& Taylor, S. A. (1992). Measuring service quality: A reexamination and extension.

Journal of Marketing, 56(3), 55-68.

Cronin, J., Brady, M. and Hult, G., 2000. Assessing the effects of quality value and customer satisfaction on consumer behavioural intentions in service environments, Journal of Retailing, 76(2), 193-218 Zeithaml, V. A., \& Bitner, M. J. (2003). Customer perceptions of service. Boston, MA: McGraw-Hill, 83- 